www.czasopisma.marszalek.com.pl/pl/10-15804/npw

\author{
Aleksander Ksawery Olech \\ Akademia Sztuki Wojennej \\ ORCID ID: https://orcid.org/0000-0002-3793-5913
}

\title{
Współczesne zagrożenia terrorystyczne w Republice Czeskiej
}

\section{Contemporary terrorist threats in the Czech Republic}

\section{Abstract}

Terrorism has been evolving and taking different forms since the beginning of the XXI century. It is closely related to the geopolitical situation in the world. The development of research of safety indicates evidently that terrorism currently constitutes one of the biggest threats to the security of countries. That is why the analysis of terrorist threats in Central European countries, including the Czech Republic, seems to be indispensable.

It is the Western European countries that are struggling today with intrastate terrorism whose effects lead to destabilization of national integrity and jeopardise social security. This situation is also important for neighbouring countries and international organisations to which they belong, such as the European Union or NATO. Data collected between 2014 and 2019 shows that the Czech Republic has improved its terrorist threat combating system and it is constantly reducing the impact of threats on the situation in the country.

Terrorism as a phenomenon, and at the same time a kind of weapon for the increasing number of its proponents, needs to be acknowledged immediately. Its complexity imposes determining ways of countervailing it in the future. The presented analysis is a sort of study on cases in the context of threats with the characteristic of terrorism in the Czech Republic.

Keywords: Czech Republic, terrorism, Central Europe, threats, radicalism 


\section{Современные террористические угрозы в Чехии}

\section{Аннотация}

C начала XXI века терроризм развивается и принимает различные формы. Это тесно связано с геополитической ситуацией в мире. Развитие исследований в области безопасности однозначно указывает на то, что сегодня терроризм является одной из самых больших угроз государственной безопасности. По этой причине представляется необходимым провести анализ террористических угроз в странах Центральной Европы, а значит и в Чешской Республике.

Сегодня западноевропейские страны сталкиваются с внутригосударственным терроризмом, последствия которого дестабилизируют национальную целостность и угрожают социальной безопасности. Эта ситуация важна и для соседних с ними стран, и для международных организаций, к которым они принадлежат, таких как Европейский Союз и НАТО. Согласно данным, собранным в ходе исследований в период 2014-2019 годов, Чешская Республика усовершенствовала свою систему борьбы с террористическими угрозами и постоянно снижает их воздействие на ситуацию в стране.

Терроризм, как явление и в то же время форма оружия для всё большего числа его сторонников, требует немедленного внимания к нему. Его сложность заставляет искать способы борьбы с ним в будущем. Представленный анализ является своего рода тематическим исследованием в контексте террористических угроз в Чешской Республике.

Ключевые слова: Чешская Республика, терроризм, Центральная Европа, угрозы, радикализм

\section{Wstęp}

Terroryzm jako zjawisko społeczne bezpośrednio lub pośrednio wpływa _ na życie jednostek, narodów i państw. Charakteryzuje się ogromną dynamiką związaną z rozwojem politycznym, technologicznym i wiedzą ludzką. Ze względu na powyższe czynniki rozszerzyły się możliwości dostępu do środków, które zagrażają lub negatywnie wpływają na demokratyczny porządek. Podstawowym kryterium definicji terroryzmu jest uznanie go za przestępstwo (Brzybohatý, 1999, s. 7, 11). Zjawisko to stale ewoluuje, dlatego jego definicje również nie mogą pozostawać statyczne (Filipec, 2017, s. 12; Marszałek-Kawa, Plecka, Hołub, 2018). 
Analiza terroryzmu i podejmowanych $\mathrm{w}$ jego ramach działań wiąże się z próbą opisania należących do niego zwrotów i pojęć. Interpretowanie tego terminu, w związku z licznymi modyfikacjami, poszerzeniami i dopasowywaniem do narodowych strategii, jest konieczne do określenia podmiotów, które będą odpowiedzialne za walkę z terroryzmem. Podstawą w badaniach jest odróżnienie terroru od terroryzmu (Iulian, 2017). Pierwsze to dominacja podmiotu silniejszego nad słabszym, objawiająca się jako dyktatura, totalitaryzm, tyrania, reżim, despotyzm. Terroryzm natomiast (w pierwotnych określeniach) to agresja, przemoc, atak słabszych przeciwko silniejszym, w celu obalenia ich władzy, wywołania określonych działań, zwrócenia uwagi na problem lub demonstracji sił. W bieżącej chwili jest często kojarzony $z$ atakami na tle religijnym (zwłaszcza związanym $z$ islamem), które uderzają bezpośrednio w obywateli i struktury określonego państwa. Są za niego odpowiedzialne organizacje i grupy terrorystyczne, których motywy i idee są uzasadnione wiarą, celami politycznymi, ekonomicznymi, społecznymi, narodowościowymi, a nawet ekologicznymi (Zabłocki, 2013, s. 51-52).

Zaprezentowane poniżej wyniki analizy mają na celu ujęcie w jak najszerszej perspektywie zagrożeń terrorystycznych pojawiających się na terytorium Republiki Czeskiej w ciągu ostatnich pięciu lat. Pod uwagę zostały wzięte przede wszystkim niebezpieczeństwa, które w swojej formie, idei, obszarze i charakterystyce mogą zostać lub są ujęte jako terrorystyczne. Należy zatem traktować tę analizę jako studium przypadków. Ze względu na brak jednolitej międzynarodowej definicji terroryzmu, która byłaby w czynnym użytkowaniu, autor opiera się na ogólnej deskrypcji tego zjawiska w krajach Unii Europejskiej. W ramach prowadzonych badań opisano także przebieg ewolucji współczesnych zagrożeń terrorystycznych w Republice Czeskiej.

Terroryzm nie występuje współcześnie na terytorium Czech, ale cały czas istnieje zagrożenie jego ekspansji z zagranicy. Dlatego też istotne jest ponowne pochylenie się nad tym zjawiskiem oraz poddanie go analizie. Jest to bardzo ważne ze względu na dynamizm przemian w środowisku geopolityki i bezpieczeństwa, a także z uwagi na ważną pozycję Republiki Czeskiej w Europie Centralnej. Należy zaznaczyć, że Czechy są m.in. członkiem Unii Europejskiej, NATO, OECD, OBWE, Rady Europy i Grupy Wyszehradzkiej (V4). 
W opracowaniu przedstawiono również prawdopodobne kierunki tych zmian. Główne czynniki, które były brane pod uwagę, to współcześnie pojawiające się niebezpieczeństwa, sytuacja w strefie Schengen, a także możliwy wzrost zagrożeń terrorystycznych na Bliskim Wschodzie i w Afryce, które mogą negatywnie oddziaływać na państwa Europy Centralnej. Może to być spowodowane wzmożoną migracją, radykalizacją obywateli państw europejskich, a także nasileniem się nastrojów antymuzułmańskich, ksenofobicznych oraz ultraprawicowych. Wnikliwy przegląd uzyskanych materiałów oraz wielofazowa kwerenda pozwoliły na określenie przyszłych trendów w bezpieczeństwie narodowym Republiki Czeskiej.

\section{Analiza zagrożeń terrorystycznych w Republice Czeskiej w latach 2014-2019}

W 2018 roku United Nations Office On Drugs And Crime (UNODC - Biuro Narodów Zjednoczonych ds. Narkotyków i Przestępczości) określiło terroryzm jako wykorzystywanie metody przymusu lub grożenie przemocą w celu szerzenia strachu oraz osiągnięcia celów politycznych lub ideologicznych (United Nations Office On Drugs And Crime, 2018, s. 1).

Ministerstwo Spraw Wewnętrznych Czech współcześnie klasyfikuje zagrożenia terrorystyczne ze względu na cztery motywy działania sprawców:

1. radykalizm islamski,

2. ekstremizm polityczny,

3. terroryści działający samotnie („samotne wilki”),

4. zagraniczni bojownicy.

Natomiast wśród współczesnych zagrożeń dla Republiki Czeskiej, przygotowanych na podstawie National Security Audit, należy przede wszystkim wyróżnić: ataki podejmowane przez samodzielnych aktorów (średnie ryzyko) oraz zagranicznych bojowników (średnie ryzyko). Istnieje niebezpieczeństwo (średnie ryzyko), że terroryści mogą wykorzystywać Czechy do pozyskiwania lub przekazywania środków finansowych (Ministry of the Interior of the Czech Republic, 2016).

W badaniach nad terroryzmem należy wziąć pod uwagę dane australijskiego centrum badawczego Institute for Economics and Peace (IEP), które co roku publikuje raport Global Terrorism Index - Measuring the Impact of 
Terrorism. Porównuje on tendencje terrorystyczne zmieniające się w czasie i pod względem geograficznym, metody ataku, poziom zaangażowania krajowych i międzynarodowych organizacji terrorystycznych oraz przybliża kontekst gospodarczy i polityczny. Zawiera także szereg wskaźników społeczno-ekonomicznych, które określają kluczowe czynniki związane z funkcjonowaniem terroryzmu i bezpieczeństwem społecznym. Jak wynika z danych zgromadzonych w opracowaniach z lat 2014-2019, Republika Czeska usprawniła system zwalczania zagrożeń terrorystycznych oraz stale redukuje ich wpływ na sytuację w państwie.

\section{Rok 2014}

W 2014 roku Republika Czeska została sklasyfikowana na 85. miejscu na świecie pod względem wpływu terroryzmu na sytuację w kraju przez Institute for Economics and Peace. Według IEP na przełomie 2013/2014 roku odnotowano jeden atak terrorystyczny, w którym zginęła jedna osoba (Institute for Economics \& Peace, 2014, s. 9, 35). Mogło to dotyczyć wypadku, w którym zginął palestyński dyplomata. Niektóre media opisały pierwotnie, że był to atak terrorystyczny. Śmierć poniósł palestyński dyplomata Jamal al-Jamal, który zginął przez wybuch systemu zabezpieczenia sejfu (Smale, de Goeij, 2014). To wydarzenie nie zostało jednak rozpoznane przez czeskie służby jako atak terrorystyczny, a jako nieszczęśliwy wypadek (Holakovský, 2014). Należy przy tym wskazać, że w 2014 roku w raporcie IEP Czechy były sklasyfikowane tuż za Niemcami, ale przed Belgią i Holandią. Wpływ na to mogło mieć aresztowanie w Czechach pięciu osób, w tym jednego dżihadysty, który był obywatelem Bośni i podróżował z Pragi do Stambułu z fałszywymi dokumentami. Pozostali zatrzymani zostali określeni jako lewicowi anarchiści (Teroristé vyhledávají..., 2016). Ponadto pięciu czeskich żołnierzy zginęło w samobójczym zamachu w pobliżu bazy lotniczej Bagram we wschodnim Afganistanie. Ataku dokonano w godzinach porannych, gdy żołnierze przeprowadzali rutynowy patrol przy bazie lotniczej (Jůn, 2014). 


\section{Rok 2015}

Rok później w tej samej klasyfikacji Czechy zostały umieszczone na 68. miejscu na świecie i na 14. miejscu w Europie. W raporcie IEP określono, że na terenie kraju doszło do trzech ataków o charakterze terrorystycznym, w których zginęła jedna osoba (Institute for Economics \& Peace, 2015, s. 11, 51). Prezydent Czech w styczniu, w 70. rocznicę wyzwolenia obozu koncentracyjnego Auschwitz, na konferencji „Let My People Live!” wygłosił oświadczenie. Mówił o zagrożeniu ze strony radykalnych islamistów, przyrównując go do superholocaustu (cen, 2015). Następnie w sierpniu 2015 roku zaznaczył, że należy zwrócić uwagę na przyjeżdżających migrantów, którzy mogą być wysyłani przez Państwo Islamskie jako uśpione komórki terrorystyczne. Miloš Zeman dodał, że Unia Europejska powinna lepiej chronić swoje granice zewnętrzne, a jeśli to zawiedzie, wówczas Czechy skoncentrują się na zatrzymaniu migrantów na granicy, a następnie odeślą ich (Zeman: Refugees..., 2015). Służby bezpieczeństwa w swoich raportach także zauważały wykorzystanie Czech jako kraju tranzytowego pomiędzy Bliskim Wschodem i Europą Zachodnią. Wskazano, że z tej drogi korzystali głównie islamscy radykałowie (Radek Rozvoral..., 2015). Istniało więc potencjalne zagrożenie atakami terrorystycznymi w Czechach, związane z działalnością Państwa Islamskiego. Republika Czeska była wśród 15 państw członkowskich UE, w których aresztowano osoby podejrzewane o terroryzm islamski. Ogólnie w 2015 roku terroryści zaatakowali co najmniej raz w 92 krajach. Ponad 55 procent tych działań było skoncentrowanych w pięciu najbardziej niebezpiecznych regionach, tj. w Iraku, Afganistanie, Nigerii, Pakistanie i Syrii.

\section{Rok 2016}

W kolejnym roku Republika Czeska zajęła niższą lokatę w klasyfikacji IEP, znalazłszy się na 71. miejscu na świecie (jednakże przed m.in. Wenezuelą, Brazylią, Madagaskarem, Hiszpanią i Belgią) (Institute for Economics \& Peace, 2016, s. 11,94). Także w swoim raporcie Ministerstwo Spraw Wewnętrznych Republiki Czeskiej (Ministerstvo vnitra České republiky) zwróciło uwage na zagrożenia terrorystyczne w 2015 i 2016 roku. Pod uwagę wzięto przede 
wszystkim ataki terrorystyczne, które wystąpiły w Europie. Pojawiło się ryzyko zamachu na terytorium Czech, dlatego też podjęto działania i wprowadzono środki, które miały na celu zmniejszenie szansy na wystąpienie podobnych ataków oraz zminimalizowanie ich potencjalnego wpływu na stan bezpieczeństwa w kraju (Ministerstvo vnitra České republiky, 2017, s. 4). W 2016 roku zwrócono uwagę na zagrożenia wynikające z migracji i zmian w społeczeństwie. Wiązać się to mogło z radykalizacją społeczeństwa, która przejawiała się zarówno powstawaniem grup islamofobicznych, antymigranckich, jak i podżeganiem do nienawiści (Ministerstvo vnitra České republiky, 2017, s. 47). Może to prowadzić wykluczenia społecznego oraz zwiększać ryzyko zamachu terrorystycznego zarówno ze strony lewicowych, jak i prawicowych ugrupowań.

Jednym $\mathrm{z}$ incydentów, który stanowił zagrożenie ${ }^{1}$ oraz miał charakter międzynarodowy, była próba zamachu na Angelę Merkel podczas jej wizyty w Pradze w sierpniu 2016 roku. Czeska policja zatrzymała mężczyznę, który nie był uzbrojony, ale przedmioty znalezione w jego samochodzie można było łatwo wykorzystać jako broń. Próbował on dołączyć do kolumny samochodów podczas wizyty niemieckiej kanclerz w stolicy Czech. Policja zagrodziła mu drogę oraz musiała zagrozić użyciem broni (Utok na Merkelovou..., 2016).

Według raportu Europolu TESAT - European Union, Terrorism situation and trend report 2017 w 2016 roku w Czechach aresztowano jedną osobę podejrzewaną o dżihadyzm oraz jedną o lewicowych poglądach. Co ważne, w sąsiadującej Austrii zatrzymano aż 34 osoby, z czego 30 dżihadystów i 4 separatystów (Europol, 2017, s. 50). W 2016 roku nie poczyniono żadnych przygotowań do przeprowadzenia ataku terrorystycznego w Czechach. Jedyne przestępstwo, które można uznać za islamski terroryzm, popełnił dwudziestoletni mężczyzna z regionu pilzneńskiego. Jan Silovsky (obywatel Czech) w lutym 2016 roku poleciał do Turcji, aby dostać się do Syrii i dołączyć do Państwa Islamskiego. Został zatrzymany przez władze tureckie i odesłany do Czech, gdzie przyznał się do winy. Swoje działania przygotował sam, bez współpracy z inną osobą (Ministerstvo vnitra České republiky, 2017, s. 62). Zgodnie $\mathrm{z}$ aktem oskarżenia z grudnia 2016 roku został skazany na

1 Został uznany za zagrożenie o charakterze terrorystycznym przez Institute for Economics and Peace (IEP). 
sześć lat więzienia za propagowanie terroryzmu, ale groziło mu 12 lat. Sąd odrzucił jego wniosek o wcześniejsze zwolnienie na początku października 2019 roku (Čech..., 2019).

Biuro Analiz Finansowych (Finanční analytický úřad - FAÚ), podlegające ministerstwu finansów, działające jako jednostka wywiadu finansowego, otrzymało w 2016 roku ogółem 2948 powiadomień o podejrzanych transakcjach (w 2015 roku były 2963 takie powiadomienia). W niektórych sprawach część środków została przejęte w związku z przeciwdziałaniem praniu pieniędzy i finansowaniu terroryzmu. Łączna suma środków zapewnionych przez FAÚ w 2016 roku wyniosła 3836 mln koron czeskich (Ministerstvo vnitra České republiky, 2017, s. 31).

We wrześniu 2016 roku zatrzymano w Rybniku obywatela Maroka Mourada T. Był on bliskim współpracownikiem Abdelhamida Abaaouda, członka Państwa Islamskiego, który odpowiadał za organizację ataków terrorystycznych we Francji w 2015 roku. W toku postępowania ustalono, że Mourad T. od grudnia 2014 roku do września 2016 roku przebywał w Polsce, a także na terenie krajów Unii Europejskiej takich jak: Austria, Grecja, Węgry, a także w Serbii oraz Turcji. Razem z innymi osobami należał do międzynarodowej organizacji terrorystycznej. Według oskarżenia obywatel Maroka miał sprawdzać trasy, po których można się poruszać, sprawdzać, czy imigranci są kontrolowani i na ile te kontrole w różnych państwach są szczegółowe. Następnie przekazywał te informacje innym terrorystom, którzy podróżowali po Europie. Mourad T. miał przybyć do Polski z Czech. Marokańczyk został skazany w Katowicach na trzy i pół roku pozbawienia wolności za przynależność do ISIS i trzy miesiące za przestępstwa mniejszej wagi. Według informacji uzyskanych w toku śledztwa nie planował ataku terrorystycznego w Polsce ani w Czechach.

\section{Rok 2017}

W roku 2017 eksperci z Institute for Economics and Peace zwrócili uwagę na znaczną poprawę sytuacji w Czechach, zwłaszcza jeśli chodzi o powstrzymywanie zagrożeń o charakterze terrorystycznym (Institute for Economics \& Peace, 2017, s. 10,55).W raporcie z tego roku Republika zajmuje 83. miejsce na świecie. 
Spośród zdarzeń o charakterze terrorystycznym na szczególną uwagę zasługuje działanie 71-letniego obywatela Czech Jaromira Baldy. W czerwcu 2017 roku wycią on dwa drzewa przy torach kolejowych, czym spowodował dwa wypadki (bad, 2019). Pociągi uderzyły w zapory z prędkością 74 i 67 kilometrów na godzinę. Nikt nie został ranny. Sprawca porozrzucał w miejscu zdarzenia ulotki z napisami „Allah Akbar”. Chciał w ten sposób skierować oskarżenia na społeczność muzułmańską w Czechach. Zgodnie z wyrokiem Sądu Najwyższego z 2019 roku J. Balda przeprowadził atak terrorystyczny (jest pierwszą osobą skazaną w Czechach za zamach terrorystyczny). Skazany tłumaczył się, że boi się zamachów podobnych do tych, które zdarzyły się we Francji i w Niemczech.

W 2017 roku czeskie służby działające na rzecz bezpieczeństwa kontynuowały analizę wpływu zagrożeń ze strony dżihadystów oraz ze strony osób i grup, które mogły ulec radykalizacji. Pod uwagę były brane ekstremistyczne ideologie, które mogły mieć wpływ na społeczeństwo Republiki Czeskiej, a tym samym zachęcić do ataku terrorystycznego, jak to działo się we Francji lub w Belgii. Główne kierunki dochodzeń dotyczyły islamofobii, działalności antymuzłumańskiej, a także retoryki związanej z napięciami wokół uznania Jerozolimy na stolicę Izraela. Czeska policja prowadziła dochodzenia w stosunku do kilku osób, które mogły udzielać wsparcia finansowego lub logistycznego grupom terrorystycznym za granicą. Kilka osób z Czech było zaangażowanych w działania w Iraku oraz Syrii. Przesłuchano kilka osób podejrzanych o organizowanie szkoleń terrorystycznych, zapewnianie terrorystom opieki zdrowotnej lub innego materialnego wsparcia. Czeskie służby uzyskały także informacje o wyjeździe dwóch Czechów do Syrii. Po raz pierwszy obywatele czescy znaleźli się wśród zagranicznych bojowników, czym podwyższyli ryzyko związane ze wspieraniem przestępców. Jeśli chodzi jednak o zagrożenia wewnętrzne, to czeska społeczność muzułmańska została określona jako niestanowiąca zagrożenia i mająca umiarkowany wpływ na niebezpieczeństwa o charakterze terrorystycznym (Ministry of the Interior of the Czech Republic, 2018, s. 48).

19 kwietnia 2017 roku rząd zatwierdził Koncepcję ochrony celów miękkich na lata 2017-2020 (Koncepci ochrany měkkých cílů pro roky 2017-2020), opartą na pakiecie antyterrorystycznym zatwierdzonym 31 sierpnia 2016 roku, który zawiera metody i środki zmniejszające ryzyko 
wystąpienia ataku terrorystycznego. Celem tego przedsięwzięcia jest stworzenie krajowego systemu ochrony celów miękkich, który umożliwi elastyczną, kompleksową i szybką reakcję na zagrożenia atakami. Jest to spowodowane zarówno sytuacją za granicą, jak i w samych Czechach ${ }^{2}$. Warto dodać, że terroryzm został określony w Czechach przez Centre Against Terrorism and Hybrid Threats (CTHH, Centrum proti terorismu a hybridním hrozbám) jako równorzędny wobec zagrożeń hybrydowych.

Centrum rozpoczęło działalność w ministerstwie spraw wewnętrznych 1 stycznia 2017 roku. Jest to wyspecjalizowana komórka analityczna, której działania koncentrują się na zagrożeniach (szczególnie hybrydowych), które podlegają analizie wchodzącej w zakres kompetencji ministerstwa spraw wewnętrznych. Głównym zadaniem CTHH jest monitorowanie zagrożeń bezpośrednio związanych $\mathrm{z}$ bezpieczeństwem wewnętrznym państwa. Działalność tej komórki polega na analizowaniu zagrożeń i potencjalnych incydentów związanych z terroryzmem, atakami na „cele miękkie”, migracją, ekstremizmem, zgromadzeniami o charakterze masowym, różnymi działaniami przestępczymi, a także oceną kampanii dezinformacyjnych i innych przejawów obcych wpływów. Centrum na podstawie monitorowania ocenia wykryte problemy i przedstawia propozycje rozwiązań merytorycznych i legislacyjnych, które zostaną wdrożone w razie potrzeby. Warto jednak zaznaczyć, że to ministerstwo obrony odpowiada za walkę z zagrożeniami hybrydowymi i terroryzmem.

We wrześniu 2017 roku odbyło się doroczne spotkanie rządów Czech i Słowacji w miasteczku Lednice na Morawach. Omówiono aktualne kwestie dotyczące współpracy, ochrony granic, kryzysu migracyjnego i walki z terroryzmem. W listopadzie 2017 roku czeski minister spraw wewnętrznych odwiedził Słowację w celu omówienia przyszłej współpracy dwustronnej.

W 2017 roku Finanční analytický úřad otrzymał 3524 zgłoszenia o podejrzanych transakcjach. Część z nich dotyczyła finansowania terroryzmu. Na działalność Biura wydano w sumie $2146 \mathrm{mln}$ koron czeskich. Był to również

2 Sekcja poświęcona walce $\mathrm{z}$ terroryzmem i ochronie celów miękkich jest regularnie aktualizowana na stronie internetowej Centrum przeciwko terroryzmowi i zagrożeniom hybrydowym (Centra proti terorismu a hybridním hrozbám): http://www.mvcr.cz/cthh/ clanek/terorismusweb-dokumenty-dokumenty.aspx 
pierwszy rok, w którym FAÚ działał jako niezależny organ (Ministry of the Interior of the Czech Republic, 2018, s. 21).

\section{Rok 2018}

W 2018 roku nastąpiła kolejna poprawa w sytuacji Czech pod względem wpływu terroryzmu na stan bezpieczeństwa. Kraj z Europy Centralnej został umieszczony na 87. miejscu na świecie. Jest to poprawa o trzy miejsca w porównaniu z poprzedzającym rokiem i aż o 16 względem 2015 roku (Institute for Economics \& Peace, 2017, s. 9).

Finanční analytický úřad koncentrował się na zwalczaniu finansowania terroryzmu. Współpraca ze wszystkimi zainteresowanymi stronami na poziomie krajowym i międzynarodowym uległa intensyfikacji. Organizacja otrzymała 2362 wnioski dotyczące podejrzanych o naruszenie przepisów podatkowych, celnych lub w związku z finansowaniem terroryzmu. Prace FAÚ zostały pozytywnie ocenione przez komisję MONEYVAL (Committee of Experts on the Evaluation of Anti-Money Laundering Measures) (Ministerstvo vnitra České republiky, 2019b, s. 26).

W marcu 2018 roku czeska policja była gospodarzem ważnej międzynarodowej konferencji Interpol NEXUS, która odbyła się w Pradze. Priorytetem podczas wydarzenia było omówienie poprawy bezpieczeństwa na świecie i w Europie. Spotkanie koncentrowało się na zagrożeniach ze strony zagranicznych bojowników oraz atakach terrorystycznych przeprowadzanych przez „samotne wilki” lub w wyniku rozwoju home grown terrorism. Jest to rodzaj terroryzmu ukierunkowany na atakowanie kultury Europy oraz zabijanie jej mieszkańców. Zazwyczaj terrorystami stają się osoby wychowane w europejskiej kulturze, ale będące ortodoksyjnymi wyznawcami islamu. Następuje ich stanowcza radykalizacja ${ }^{3}$, która prowadzi do tego, że dokonują zamachów na terytorium państwa, którego obywatelstwo mają od urodzenia (Adamczuk, 2011, s. 60-62). Przykładem takich działań był zamach z 23 marca 2018 roku w miejscowości Carcassonne na południu Francji, podczas

3 Radykalizacja terrorystyczna - zjawisko przejmowania przez ludzi opinii, poglądów i idei, która mogą doprowadzić do popełnienia (umotywowania) ataku terrorystycznego (Deptała, 2011, s. 64). 
którego terrorysta zabił cztery osoby i 15 poważnie ranił (Mareschal, Piquet, 2018). Posiadał on obywatelstwo Republiki Francuskiej oraz mieszkał tam na stałe (Attaques..., 2018). Ten rodzaj terroryzmu jest określany również jako socjologiczne kuriozum, ponieważ religia dominuje nad wpojonymi przez państwo zasadami (Speckhard, 2009, s. 146-151).

Warto wspomnieć oskarżenie o terroryzm byłego praskiego imama Samera Shehadeha, jego brata Omara i szwagierki Fatimy (wcześniej: Kristyna Hudkova). Obaj bracia pochodzą z Palestyny. Samer wcześniej studiował islam w Arabii Saudyjskiej. Na początku listopada 2018 roku czeska policja zatrzymała byłego imama ze względu na jego działalność terrorystyczną i współpracę z organizacją Jabhat Fatah al-Sham ówcześnie jako Al-Nusra Front (w lipcu 2016 roku przywódca grupy Abu Muhammad al-Golani ogłosił formalne odłączenie od Al-Kaidy i zmianę nazwy grupy z Jabhat al-Nusra na Jabhat Fateh al-Sham) (Nusra Front..., b.d.). Według prokuratorów Samer Shehadeh pomógł swemu bratu udać się do Syrii w listopadzie 2016 roku, przekazując kontakty do innych terrorystów, ustalając szczegóły podróży oraz przekazując pieniądze na udział w wojnie domowej i konflikcie toczonym przeciwko rządowi syryjskiemu. Następnie umożliwił Omarowi poślubienie Kristyny Hudkovej przez Internet, a później pomógł jej dołączyć do męża w Syrii. Oskarżony przyznał się do winy, ale nie uważał, aby jako działania były przestępstwem lub były niezgodne z prawem. Były imam nie uznaje Jabhat Fateh al-Sham za organizację terrorystyczną. Twierdził ponadto, że nie akceptuje żadnej decyzji czeskich sądów, ponieważ nie podlegają one jurysdykcji islamskiego prawa szariatu. Samer Shehadeh, który został zatrzymany w listopadzie 2018 roku w Jordanii, stanął przed czeskim sądem 7 stycznia 2020 roku. Będzie odpowiadał nie tylko za promowanie terroryzmu, ale również za wykorzystywanie pieniędzy uzyskanych z celów charytatywnych na finansowanie i wspieranie organizacji terrorystycznych. Grozi mu do 15 lat więzienia (Accused..., 2020). Dwie pozostałe osoby oskarżone o terroryzm są wciąż poszukiwane.

Kluczowy w całej sprawie jest fakt, że w 2016 roku imam zwrócił na siebie uwagę wygłaszanymi publicznie radykalnymi poglądami i oświadczeniami. Był on znany m.in. z tego, że wysyłał za pośrednictwem aplikacji mobilnej WhatsApp wiadomości do innych wyznawców islamu na zamkniętej grupie. Nawoływał, aby nie brali udziału w akcjach przeciwko terroryzmowi, 
zwłaszcza wspólnie z chrześcijanami (10 sierpnia 2016 roku na praskim placu Jerzego z Podiebradów odbyła się demonstracja przeciwko terroryzmowi. Uczestniczyli w niej zarówno muzułmanie, jak i katolicy). Imam miał być obserwowany przez służby bezpieczeństwa już dużo wcześniej, gdyż jego postawa wskazywała na to, iż ulegał radykalizacji (Slonková, 2016).

Należy dodać, że Samer Shehadeh był przesłuchiwany także w sprawie Dominika Kobulnickýego. Obaj mieli się kilkukrotnie spotkać, między innymi w meczecie przy ulicy Opletalovej w Pradze. Kobulnický (przyjmując imię Abdul Rahman), który jest z pochodzenia Słowakiem, został aresztowany w grudniu 2017 roku. Przechowywał w swoim mieszkaniu w Pradze chemikalia do produkcji materiałów wybuchowych. Na jego komputerze znaleziono filmy z przedstawicielami Państwa Islamskiego, a w sieci promował zafascynowanie islamem oraz symbole ISIS i Emiratu Kaukaskiego. W połowie listopada 2019 roku został skazany na sześć i pół roku pozbawienia wolności za podejmowane działań stwarzających ogólne zagrożenie, a nie za przygotowywanie ataku terrorystycznego. Oskarżony przyznał się także podczas rozprawy, że w 2015 roku rozważał atak terrorystyczny, a celem miał być dworzec autobusowy w Preszowie (Prešov) (Bohata, 2019). Jest to jednocześnie pierwszy obywatel Słowacji i wyznawca islamu, który został skazany na karę więzienia za działania o charakterze terrorystycznym (First Slovak..., 2019).

Ministerstwo transportu (Ministerstvo dopravy) w 2018 roku przygotowało, a następnie 18 stycznia 2019 roku uruchomiło program na rzecz bezpieczeństwa: „Zwiększenie ochrony i bezpieczeństwa ważnych węzłów transportowych jako możliwych miękkich celów - 2019” („Zvýšení ochrany a zabezpečení významných dopravních uzlů jako možných měkkých cílů - 2019”). 27 czerwca 2019 roku ministerstwo transportu zorganizowało seminarium poświęcone ochronie miękkich celów w transporcie i pojawiających się zagrożeń w roku 2020 (Ministerstvo dopravy, 2019).

Raport ministerstwa spraw wewnętrznych z 2018 roku zwraca również uwagę na zjawisko radykalizacji, które może prowadzić do poważnych przestępstw z użyciem przemocy lub do ataków terrorystycznych. Ważne, aby nieustannie nadzorować poziom radykalizacji w społeczeństwie. Jakiekolwiek zmiany lub odchylenia w kierunku m.in. prawicowych, lewicowych, separatystycznych lub islamistycznych ruchów muszą być natychmiast objęte 
nadzorem. Jest to długofalowa strategia utrzymania bezpieczeństwa w kraju poprzez stałą analizę pojawiających się niebezpieczeństw. Republika Czeska znalazła się wśród pięciu krajów w Unii Europejskiej, które aresztowały osoby podejrzane o prawicowy terroryzm w 2018 roku. W całej wspólnocie były 44 takie przypadki, o 10 więcej niż zatrzymań terrorystów lewicowych. W 2015 roku zatrzymano w UE 11 prawicowych terrorystów i 67 lewicowych. Jak można zauważyć, na przestrzeni trzech lat zmieniła się tendencja działań poszczególnych ugrupowań (Europol, 2019, s. 9).

W tym samym roku agencja czeskie służby specjalne poinformowały (Bezpečnostní informační služba - BIS), że w 2017 roku wraz z zagranicznymi partnerami wykryła, obserwowała i ostatecznie zamknęła sieci serwerów hakerskich w Czechach (Bezpečnostní informační služba, 2019). Miały one być prowadzone przez bojownika organizacji terrorystycznej Hezbollah. Celem terrorystów było atakowanie urządzeń mobilnych na całym świecie za pośrednictwem mediów społecznościowych. Hakerzy uzyskiwali dostęp poprzez instalowanie szkodliwej aplikacji. Terroryści mieli nieprzerwany wgląd do danych osobowych, kontaktów, zdjęć, połączeń, wiadomości SMS, informacji o lokalizacji właściciela urządzenia, a także możliwość nagrywania dźwięków wokół urządzenia.

Policja w 2018 roku oskarżyła kilka osób o wspieranie lub finansowanie terroryzmu o podłożu religijnym. Łącznie służby wykryły 179 przestępstw o charakterze ekstremistycznym, a 54 osoby zostały skazane (Ministerstvo vnitra České republiky, 2019a, s. 7).

\section{Rok 2019}

Rok 2019 w ujęciu Global Terrorism Index wskazuje na znaczną poprawę sytuacji w Republice Czeskiej. Została ona umieszczona na 102. miejscu na świecie (za Danią i przed Azerbejdżanem) pod względem wpływu terroryzmu na bezpieczeństwo państwa. Jest to poprawa aż o 15 miejsc względem roku poprzedniego (Institute for Economics \& Peace, 2019, s. 9). Za incydent, który mógłby mieć charakter terrorystyczny, należy wziąć atak z bronią w szpitalu w Ostrawie. Siedem osób zostało zabitych, dziewięć - rannych, a do podjęcia czynności kontrterrorystycznych skierowano policję i specjalny oddział antyterrorystyczny. Sprawca Ctirad Vitásek uciekł, a następnie 
popełnił samobójstwo. Działanie to jednak nie zostało uznane za terrorystyczne, gdyż napastnik miał problemy natury psychicznej (Masakr...,2019). Strzelanina w ostrawskim szpitalu jest drugim tak tragicznym zdarzeniem w historii Republiki Czeskiej. W lutym 2015 roku w restauracji w Uherskim Brodzie mężczyzna zastrzelił osiem osób, a następnie odebrał sobie życie. Prawdopodobnie również miał problemy natury psychicznej.

W marcu czeskie służby zatrzymały w Pradze dwójkę obywateli Iraku. Byli oni podejrzewani o działania o charakterze terrorystycznym, ponieważ w 2018 roku dokonali ataku na pociągi w Niemczech. Według informacji przekazanych przez MSW Austrii, które wydało międzynarodowy nakaz aresztowania, sprawcy mieli zawiesić stalową linę na torach pomiędzy Monachium i Norymbergą, uszkadzając pociągi. Następnie raz jeszcze próbowali uszkodzić pociąg, który wyjeżdżał z Berlina. Według śledczych podejrzani źle zamontowali liny i dlatego nikt nie został ranny. W pobliżu miejsca ataku znaleziono flagę Państwa Islamskiego (Mikelionis, 2018).

Tabela 1. Pozycja Republiki Czeskiej wg Global Terrorism Index w latach 2014-2019, opisująca funkcjonowanie państwa w kontekście rozwoju terroryzmu

\begin{tabular}{|c|c|c|}
\hline Rok & Miejsce w Europie & Miejsce na świecie \\
\hline 2014 & 17. & 85. \\
\hline 2015 & 13. & 68. \\
\hline 2016 & 12. & 71. \\
\hline 2017 & 15. & 83. \\
\hline 2018 & 16. & 87. \\
\hline 2019 & 20. & 102. \\
\hline
\end{tabular}

Źródło: opracowanie własne na podstawie: IEP, Global Terrorism Index 2019 - Measuring the impact of terrorism, Sydney 2019. IEP, Global Terrorism Index 2018 - Measuring the impact of terrorism, Sydney 2018. IEP, Global Terrorism Index 2016 - Measuring the impact of terrorism, Sydney 2016. IEP, Global Terrorism Index 2014 - Measuring the impact of terrorism, Sydney 2014.

\section{Reakcja na pojawiające się zagrożenia}

Kodeks karny (ustawa nr 40/2009 Coll.) jest w Republice Czeskiej głównym zbiorem kar za terroryzm. Czeski porządek prawny definiuje atak terrorystyczny na podstawie paragrafu 311 jako „zamierzenie naruszenia 
konstytucji lub obronnej zdolności Republiki Czeskiej, zakłócenie lub zniszczenie podstawowej struktury politycznej, gospodarczej lub społecznej Republiki Czeskiej albo organizacji międzynarodowej, poważne zastraszenie ludności lub nielegalne zmuszenie rządu, innego organu publicznego albo organizacji międzynarodowej do zrobienia czegoś, poprzez spowodowanie zniszczeń lub cierpienia”. Sprawca może zostać skazany na karę od 5 do 15 lat więzienia m.in. za publiczne zachęcanie do ataków terrorystycznych oraz finansowe (lub innego rodzaju) wspieranie terrorystów lub grup. Za wyrządzenie znacznych szkód, w tym spowodowanie poważnych obrażeń lub śmierci, oraz udział w działaniach w grupy terrorystycznej grozi kara od 12 do 20 lat więzienia. Przygotowanie ataku terrorystycznego również jest karalne (Trestní zákoník č. 40/2009 Sb). Kara za finansowanie terroryzmu, wspieranie członków lub organizacji została ujęta w paragrafie $312 \mathrm{~d}$ pt. Finansowanie terroryzmu. Działanie to jest karane pozbawieniem wolności na okres od 3 do 12 lat, a oprócz tej kary również przepadkiem mienia. Sprawca podlega karze pozbawienia wolności na okres od 5 do 15 lat, jeżeli popełni przestępstwo jako członek grupy terrorystycznej w stanie wyjątkowym lub podczas wojny albo wyrządzi znaczną szkodę (Trestní zákoník č. 40/2009 Sb).

W lutym 2017 roku weszła w życie nowelizacja Kodeksu karnego, wprowadzająca ściganie karne finansowania i wspierania terroryzmu. Najważniejsze zmiany obejmowały wprowadzenie definicji grupy terrorystycznej, zdefiniowanie finansowania terroryzmu jako odrębnego przestępstwa oraz zmianę orzecznictwa w zakresie sankcji za przygotowanie ataków terrorystycznych i pomoc przy ich organizacji. Wzięto również pod uwagę takie przestępstwa jak: opuszczenie kraju w celu podjęcia działań terrorystycznych, rekrutacja do organizacji terrorystycznych, prowadzenie szkoleń, dostarczanie materiałów na szkolenie.

Pojawiające się w państwie niebezpieczeństwa terrorystyczne są analizowane i opisywane za pomocą obowiązujących stopni zagrożenia. Pierwszy poziom jest określany kolorem żółtym (první stupeň - žlutý trojúhelník), drugi - pomarańczowym (druhý stupeň - oranžový trojúhelník), a trzeci (najwyższy) - czerwonym (třetí stupeň - červený trojúhelník). Stan zagrożenia wprowadza rząd na wniosek ministra spraw wewnętrznych. Obecnie w Republice Czeskiej obowiązuje pierwszy stopień zagrożenia terrorystycznego. Ten poziom utrzymywany jest od marca 2016 roku, kiedy 
przeprowadzono atak na lotnisko Zaventem w Brukseli. Wynika to z sytuacji za granicą, członkostwa Republiki Czeskiej w strukturach euroatlantyckich oraz jej działalności międzynarodowej (Ministerstvo vnitra České republiky, 2020). Stopień ten wskazuje, że zagrożenie terrorystyczne na terytorium Republiki Czeskiej nie jest znane, ale sygnalizuje, że istnieje ogólne niebezpieczeństwo wystąpienia aktów o charakterze terrorystycznym (Ministerstvo vnitra České republiky, 2019b).

Wydaje się, że MSW jest świadome zagrożeń terrorystycznych. W opracowaniach na temat terroryzmu wskazano, że jest to zjawisko, które może zasadniczo zagrażać każdemu państwu, w tym Republice Czeskiej. Ataki lub próby zamachów na świecie oraz w Europie muszą być ostrzeżeniem dla Republiki Czeskiej. Jest to współcześnie jedno z największych wyzwań w środowisku bezpieczeństwa. Dlatego też istotna jest globalna współpraca zmierzająca ku eliminacji zagrożeń terrorystycznych w krajach UE. Zaangażowanie w tym obszarze jest ważnym wkładem w zwiększenie bezpieczeństwa w Republice Czeskiej. Jednocześnie trzeba wziąć pod uwagę możliwość przeprowadzenia ataku terrorystycznego bezpośrednio w cyberprzestrzeni (Ministerstvo vnitra České republiky, 2013).

Siły bezpieczeństwa w Czechach za największe wyzwanie w nachodzących latach uważają działania podejmowane przez „samotne wilki” (Ministerstvo vnitra České republiky, 2019a), ponieważ nie mają oni powiązań z organizacjami terrorystycznymi i działają bez pozostawiania śladu. Często terroryści po atakach przyznają, że należeli do którejś organizacji lub grupy, aby skojarzyć ich z tymi zamachami. Są to jednak informacje nieprawdziwe. Według serwisu Esri ${ }^{4}$ (2017) w Republice Czeskiej w latach 2016-2020 nie wydarzył się ani jeden atak terrorystyczny.

4 Amerykańska firma zajmująca się technologią mapowania. Współpracuje z PeaceTech Lab i korzysta $\mathrm{z}$ danych Wikipedii dotyczących ataków terrorystycznych. Organizacja zastrzega jednak, że mapa może wyświetlać fałszywe lub budzące zastrzeżenia dane, za które Esri i PeaceTech Lab nie ponoszą odpowiedzialności. Wskazuje również, że definicja terroryzmu jest z natury subiektywna, a w przypadku prezentowanej mapy jest determinowana przez społeczność, która dodaje dane do portalu. 


\section{Przyszłe zagrożenia o charakterze terrorystycznym dla Republiki Czeskiej}

Tradycyjny lokalny ekstremizm może stanowić w przyszłości największe zagrożenie dla bezpieczeństwa Czech. Ataki o charakterze międzynarodowym nie zdarzały się na razie w kraju dzięki skutecznej polityce bezpieczeństwa. Dlatego najbardziej bezpośrednie niebezpieczeństwo będzie się wiązać z rosnącą polaryzacją społeczeństwa. Można zaobserwować pewne tendencje jednoczące w działaniach skrajną prawicę, które akcentują niezgodność islamu z wartościami europejskimi i utożsamiają muzułmanów z terrorystami. $\mathrm{Z}$ drugiej strony obserwuje się wyciszanie nastrojów antyimigracyjnych w miarę przemijania kryzysu migracyjnego. Zaczynają się pojawiać napięcia w relacjach wewnątrzpaństwowych, które wynikają z potrzeby identyfikacji z wybranym ruchem lub partią. Poszczególne poglądy i sposób ich wyrażania mogą prowadzić do starć pomiędzy wyznawcami różnych partii politycznych, religii lub ideologii.

Należy zaznaczyć, ze sytuacja w Czechach ulega zmianom ze względu na działania podejmowane w państwach sąsiadujących lub mających wpływy w Czechach. Grupy ekstremistyczne ulegają deformacji szczególnie w Niemczech, w Austrii, na Słowacji oraz na Węgrzech. W tych krajach pojawią się grupy neonazistowskie lub skrajnie prawicowe. Mimo że są to pojedyncze przypadki, to mogą one mieć ogólny wpływ na działania podejmowane przez ich zwolenników w Republice Czeskiej. Wydaje się, że największym zagrożeniem wewnętrznym są normy społeczne i poglądy polityczne, które coraz bardziej ulegają skrajnościom.

Na zagrożenia o charakterze ekstremistycznym w Czechach zwracali również badacze z Uniwersytetu Masaryka w Brnie. Wskazują oni, że najnowszy impuls do prawicowego ekstremizmu pojawił się wraz z kryzysem migracyjnym w 2015 roku. Mimo że nie było zbyt wielu ataków wobec migrantów, to można zauważyć nasilenie mowy nienawiści w Internecie. Objawia się to głównie postawami antyislamskimi, mimo że w Czechach mieszka tylko około 20000 muzułmanów (według ostatniego spisu ludności z 2011 roku - 4000 wyznawców tej religii) (Mareš, Petlák, 2019). Wpływ na ten stan mają na pewno media, które prezentują różne obrazy migrantów, wyznawców poszczególnych religii, a także potencjalnych zagrożeń (Malý, 2018).Zaczyna 
dochodzić do podziałów, pojawiają się silne postawy antymigracyjne oraz spory o stosunki z Rosją i Chinami. Zwolennicy poszczególnych ruchów radykalizują się, przez co mogą podejmować działania o charakterze terrorystycznym. Ponadto indywidualne przypadki przemocy mogą być powiązane z każdym rodzajem ekstremizmu (lewicowy, prawicowy, islamski, narodowy, separatystyczny).

Nie wolno również pominąć działalności osób przebywających w kraju, jednak zależnych od grup funkcjonujących na Bliskim Wschodzie. Przykładem może być Salih Muslim, lider Partii Unii Demokratycznej (PYD). W lutym 2018 roku został zatrzymany na podstawie nakazu wydanego przez sąd w Ankarze, jednak czeski sąd zwolnił go z aresztu. Republika udzieliła wsparcia Partii Pracujących Kurdystanu (PKK) po tym, jak w Pradze odbyła się demonstracja popierająca kurdyjskiego polityka. Swój dyplomatyczny sprzeciw wobec decyzji Republiki Czeskiej wyraził turecki rząd, który uważa zarówno PKK, jak i PYD, za organizacje terrorystyczne (Kratochvílová, 2018). W przyszłych rozważaniach na temat możliwych zagrożeń o charakterze terrorystycznym w kraju należy wziąć pod uwagę także poglądy lewicowe lub ekstremistyczne. Wspieranie poszczególnych frakcji z innych państw może się realizować poprzez manifestowanie poglądów w Czechach.

Należy zwrócić uwagę na potrzebę ochrony sektora energetycznego w państwach członkowskich Unii Europejskiej, a szczególnie w Czechach. Potencjalnymi celami terrorystów mogą być rurociągi naftowe i gazowe, rafinerie, zakłady przetwarzania gazu, magazyny ropy i gazu, zbiorniki naziemne oraz stacje benzynowe. Państwo Islamskie w walce z Zachodem może podjąć takie działania, które miałyby strategiczny charakter w trwającej wojnie z terroryzmem. Dodatkowo posiadają oni zaplecze, które pozwala im na przeprowadzenie symultanicznych ataków, co udowodnili zamachami w Republice Francuskiej i w Belgii. Unia Europejska powinna zainwestować więcej pieniędzy w ochronę infrastruktury energetycznej oraz zwalczanie terroryzmu. Dodatkowo Czechy oraz inne kraje V4, powinny przeznaczyć więcej środków z budżetu prewencyjnego, aby odpowiednio zabezpieczyć infrastrukturę oraz eliminować zagrożenia ukierunkowane na sektor energetyczny (Tichý, 2016). 
Warto rozważyć także zagrożenia ze strony terroryzmu chemicznego. Jest to użycie środków chemicznych przeciwko ludności i infrastrukturze krytycznej znajdujących się na określonym obszarze (terytorium). Do skażenia dochodzi wskutek nagłego wprowadzenia do otoczenia toksycznych lub innych niebezpiecznych środków chemicznych, w wyniku czego występuje zbiorowe zagrożenie dla życia, zdrowia, mienia dużej wartości lub środowiska naturalnego (Nalepa, Popiel, 2009, s. 61-76). Takim celem mogłoby być metro w Pradze (Schüllerová, Mika, Adamec, 2014, s. 46-52).

Pojawiające się zagrożenia i możliwe scenariusze ataku terrorystycznego w Republice Czeskiej starają się przewidywać czescy specjaliści do spraw bezpieczeństwa. Odpowiednia reakcja na zamach, a tym samym wypracowanie pewnych mechanizmów, które powinni zastosować cywile, jest we współczesnym świecie niezbędna. Należy się skupić na tym, w jakich warunkach znajdą się osoby podczas ataku oraz jak w odpowiedni sposób zareagować (Eisler, Zidkova, 2017).

Nie można wykluczyć scenariusza, że terroryści będą chcieli dokonać zemsty za operacje wojskowe żołnierzy Republiki Czeskiej. Ze wszystkich państw Grupy Wyszehradzkiej Czechy były liderem wsparcia dla Iraku i Kurdów w walce z tzw. Państwem Islamskim (Kobierski, 2019). Biorąc pod uwagę akty terroryzmu, które wydarzyły się we Francji, Wielkiej Brytanii i Hiszpanii, nie sposób nie odnieść wrażenia, że każde z tych państw zapłaciło „cenę” za udział w operacjach militarnych na Bliskim Wschodzie. Kilkukrotnie ostrzegani Hiszpanie (po zamachach z 2004 roku) zdecydowali się wycofać ostatecznie kontyngenty z Iraku (Goodman, 2004). Tym bardziej pozostaje kwestią otwartą rola Czech w misjach wojskowych i konsekwencje, jakie mogą się z tym wiązać (Desítky..., 2020). Aktywność Państwa Islamskiego w Europie lub samodzielny atak zwolennika jednej z frakcji Al-Kaidy nie wydaje się czymś nienaturalnym, jeśli weźmie się pod uwagę regularność incydentów terrorystycznych w krajach Unii Europejskiej. Tym samym warto ponownie przeanalizować sytuację w kraju w kontekście pojawiających się zagrożeń. Na terytorium Czech są one realne, a za granicą mają już charakter bezpośredni (Afghan..., 2018). 


\section{Konkluzje}

Według czeskich służb rosnąca wydajność systemów bezpieczeństwa zmusza sprawców ataków terrorystycznych do nieustannego poszukiwania nowych środków, metod i celów ich ataków. Współcześnie ataki terrorystyczne są wymierzone w ludność cywilną w miejscach publicznych (miękkie cele), przeprowadzane przy użyciu bardzo prostych i tanich improwizowanych urządzeń wybuchowych. Często budowanych na podstawie instrukcji online. Wydaje się, że w przyszłości ataki terrorystyczne w Czechach mogą być przeprowadzane przez samotnych, zradykalizowanych fanatyków („samotne wilki”), bez bezpośrednich powiązań z organizacjami terrorystycznymi lub innymi strukturami (Bezpečnostní informační služba, 2020).

Jak kilkukrotnie wskazywano w raportach, obecna sytuacja międzynarodowa, a także pozycja Turcji, Iraku, Syrii i innych państw Bliskiego Wschodu, wpływa nie tylko na nielegalną migrację, ale także na terroryzm i ekstremizm. W związku z konfliktem trwającym w Syrii można założyć, że bojownicy Państwa Islamskiego lub ich zwolennicy wciąż będą napływać na kontynent europejski. Mogą oni stanowić zagrożenie dla bezpieczeństwa pod względem możliwej radykalizacji lub przygotowania ataku terrorystycznego. Wydaje się jednak, że rząd Czech jest świadomy pojawiających się niebezpieczeństw związanych z terroryzmem międzynarodowym (Ministerstvo vnitra České republiky, 2019b). Ważne jest to, w jaki sposób będzie prowadził działania prewencyjne celem zwalczania zagrożeń terrorystycznych. Republika Czeska jest obecnie postrzegana jako państwo tranzytowe, a nie jako cel podróży terrorystów (Ministerstvo vnitra České republiky, 2018).

Bardzo ważne jest branie pod uwagę nastrojów w społeczeństwie, które mają związek zarówno z uwarunkowaniami kulturalnymi, jak i religijnymi. Według niektórych czeskich mediów wielu wyznawców islamu jest postrzeganych jako potencjalne zagrożenie dla bezpieczeństwa państwa (Černý, 2015). Wynika to przede wszystkim z faktu, że muzułmanie w innych państwach, np. w Republice Francuskiej i Wielkiej Brytanii, organizowali ataki terrorystyczne. Oprócz tego pojawia się tendencja do zachowań antymuzułmańskich, która może skutkować powstawaniem napięć w społeczeństwie. Umacnianie różnic w poglądach i coraz bardziej stanowcze reakcje mogą stanowić podstawę do agresji zarówno z jednej, jak i z drugiej strony. Należy 
wziąć pod uwagę także zwolenników polityki prorosyjskiej, którzy mogą spierać się, w ramach przekonań politycznych, z narodowcami. Działalność, która ma charakter terrorystyczny, jest zazwyczaj umotywowana polityczne, religijnie lub ideologicznie. Dlatego w tym aspekcie należy szczególnie wziąć pod uwagę zagrożenia pojawiające się w Republice Czeskiej.

W związku z powyższym rząd Republiki Czeskiej powinien się przede wszystkim skoncentrować na stałym monitorowaniu napięć w społeczeństwie oraz sukcesywnie na nie reagować. Oprócz tego należy wziąć pod uwagę proces radykalizacji - w różnych kierunkach, który ma ogromny wpływ na młode osoby (vide: Republika Francuska) (Olech, 2019). Kluczowa w utrzymaniu bezpieczeństwa o charakterze wewnętrznym będzie obserwacja osób, które przyjeżdżają do kraju. W wymiarze zewnętrznym należy analizować działania podejmowane przez obywateli w kontekście ich aktywności w krajach Afryki i Bliskiego Wschodu. Dotyczy to zarówno utrzymywania kontaktów, podróży, jak i wsparcia finansowego.

Podsumowując, zagrożenia terrorystyczne, które występują w Czechach, są podobne do tych w Rzeczypospolitej Polskiej, na Węgrzech, czy na Słowacji. Należałoby przyznać, że kraje Europy Centralnej nie są współcześnie celami terrorystów. Na pewno nie w takim stopniu jak Francja, Wielka Brytania czy Rosja. Są jednak traktowane jako kraje tranzytowe lub miejsca, w których terroryści uzyskują schronienie przed wyjazdem na zachód Europy. Oprócz tego ważnym elementem w przyszłej strategii antyterrorystycznej Czech będzie ujęcie niebezpieczeństw związanych z radykalizacją społeczeństwa oraz terroryzmem o charakterze narodowym i ultraprawicowym.

\section{MGR ALEKSANDER KSAWERY OLECH}

Wydział Bezpieczeństwa Narodowego

Akademia Sztuki Wojennej

Gen. A. Chruściela 103, 00-001 Warszawa akolech@wp.pl 


\section{Bibliografia}

Accused of promoting terrorism, former Prague Imam stands by his actions in court. (2020, 8 stycznia). Kafkadesk. Pobrane z: https://kafkadesk.org/2020/01/08/accused-of-promoting-terrorism-former-prague-imam-stands-by-his-actions-in-court/.

Adamczuk, M. (2011). Rodzinny terroryzm jako zjawisko zagrażające bezpieczeństwu w Europie - Pozamilitarne aspekty bezpieczeństwa. Bezpieczeństwo Narodowe 1, $60-62$.

Adams, S. (2015, 25 sierpnia). Assassination attempt on Angela Merkel feared as armed man arrested 'trying to infiltrate German chancellor's motorcade' in Prague. Mirror. Pobrane z: www.mirror.co.uk/news/world-news/assassination -attempt-on-angela-merkel-8706692.

Afghan suicide bomber kills Czech Nato soldiers. (2018, 5 sierpnia). BBC News. Pobrane z: www.bbc.com/news/world-asia-45074383.

Attaques dans l'Aude: Radouane Lakdim était fiché S depuis 2014. (2018, 23 marca). Le Figaro. Pobrane z: https://www.lefigaro.fr/actualite-france/2018/03/23/ 01016-20180323ARTFIG00222-qui-etait-redouane-lakdim-le-terroriste-presume-des-attaques-dans-l-aude.php.

bad. (2019, 9 stycznia). Chtěl jsem udělat výzvu jako Palach, tvrdí di̊chodce obžalovaný $z$ teroristického útoku na vlak. Novinky.cz. Pobrane z: www.novinky.cz/krimi/clanek/ chtel-jsem-udelat-vyzvu-jako-palach-tvrdi-duchodce-obzalovany-z-teroristickeho-utoku-na-vlak-40267166.

Bezpečnostní informační služba. (2019, 8 października). Koudelka: BIS přispěla $k$ odkrytí a vypnutí hackerských serverů Hizballáhu. Pobrane z: https://www.bis.cz/ aktuality/koudelka-bis-prispela-k-odkryti-a-vypnuti-hackerskych-serveru-hizballahu-017f44eb.html.

Bezpečnostní informační služba. (2020, 29 stycznia). Terrorism. Pobrane z: https://www. bis.cz/terrorism/.

Bohata, J. (2019, 15 listopada). Slovák dostal šest a půl roku za obecné ohrožení, o prípravu teroru nešlo. iDNES.cz. Pobrane z: https://www.idnes.cz/praha/zpravy/ kobulnicky-muslim-slovensko-praha-islamsky-stat-terorismus-utok-soud-verdikt. A191115_103906_praha-zpravy_zuf.

Brzybohatý, M. (1999). Terorismus. Praha: Police History.

Čech, který chtěl k Islámskému státu, dřive propuštěn nebude. Soudkyně není presvědčena, že se napravil. (2019, 1 października). Irozhlas. Pobrane z: https://www.irozhlas.cz/ zpravy-domov/jan-silovsky-islamsky-stat_1910010829_pj.

cen. (2015, 27 stycznia). Dokument: Projev Miloše Zemana na konferenci Let My People Live. iDNES.cz. Pobrane z: www.idnes.cz/zpravy/domaci/projev-milose-zemana-k-vyroci-osvobozeni-osvetimi.A150127_145500_domaci_cen.

Černý, J. (2015, 16 stycznia). Nejhorší útoky. Pobrane z: https://jakubcernyjakub.blog. idnes.cz/blog.aspx?c=444106.

Deptała, D. (2011). Wybrane problemy motywacji działań terrorystycznych oraz radykalizacji. W: J. Szafrański, K. Liedel (red.). Problemy prawno-organizacyjne zwalczania terroryzmy w Polsce (59-66). Szczytno: Wyższa Szkoła Policji w Szczytnie. 
Desitky českých vojáků by mohly $v$ Africe podpořit boj proti terorismu a nelegální migraci. (2020, 6 stycznia). Lidovky.cz. Pobrane z: https://www.lidovky. $\mathrm{cz} /$ domov/cesti-vojaci-by-mohli-posilit-protiteroristickou-operaci-v-africe. A200106_135352_ln_domov_ele.

Eisler, J., Zidkova, K. (2017, 30 maja). Andor Šándor vydává novou knihu. Radí, jak přežit teroristický útok, České novinkyl.eu. Pobrane z: ceskenovinkyl.eu/ domains/ceskenovinky1.eu/2017/05/30/andor-sandor-vydava-novou-knihuradi-jak-prezit-teroristicky-utok/.

Esri.(2017).TerroristAttacks.Pobranez:http://storymaps.esri.com/stories/terrorist-attacks /?year=2017.

Europol. (2017). TESAT - European Union, Terrorism situation and trend report 2017. Hague: European Union Agency for Law Enforcement Cooperation.

Europol. (2019). TESAT - European Union, Terrorism situation and trend report 2019. Hague: European Union Agency for Law Enforcement Cooperation.

Filipec, O. (2017). Fenomén terorismus: česká perspektiva. Olomouc: Univerzita Palackého v Olomouci.

First Slovak Islamist jailed in Prague. (2019, 19 listopada). The Slovak Spectator. Pobrane z: https://spectator.sme.sk/c/22263222/the-first-slovak-islamist-jailed-in-prague. html.

Goodman, A. (2004, 19 kwietnia). Spain plans quick pullout of Iraq. CNN. Pobrane z: https://edition.cnn.com/2004/WORLD/europe/04/18/spain.withdraw/.

Holakovský, M. (2014, 1 stycznia). Za výbuch v domě velvyslance prý může manipulaces trezorem. Denik.cz. Pobrane z: https://www.denik.cz/z_domova/palestinsky-velvyslanec-zemrel-v-nemocnici-na-misto-jede-policejni-sef-cervicek.html.

Institute for Economics \& Peace. (2014). Global Terrorism Index 2014 - Measuring and Understanding the Impact of Terrorism. Sydney: Institute for Economics \& Peace.

Institute for Economics \& Peace. (2015). Global Terrorism Index 2015 - Measring and Understanding the Impact of Terrorism. Sydney: Institute for Economics \& Peace.

Institute for Economics \& Peace. (2016). Global Terrorism Index 2016 - Measuring and Understanding the Impact of Terrorism. Sydney: Institute for Economics \& Peace.

Institute for Economics \& Peace. (2017). Global Terrorism Index 2017 - Measuring and Understanding the Impact of Terrorism. Sydney 2017: Institute for Economics \& Peace.

Institute for Economics \& Peace. (2019). Global Terrorism Index 2019 - Measuring and Understanding the Impact of Terrorism. Sydney: Institute for Economics \& Peace.

Iulian, R.I. (2017). International terrorism in the 21st century - 16 years after 9/11 2001. CBU International Conference Proceedings 5, 910-914.

Jůn, D. (2014, 8 lipca). Four Czech soldiers killed in Afghan suicide bomb attack, Radio Prague Internetional. Pobrane z: https://www.radio.cz/en/section/curraffrs/ four-czech-soldiers-killed-in-afghan-suicide-bomb-attack.

Kobierski, Ł. (2019, 28 grudnia). Działania państw Grupy Wyszehradzkiej na rzecz Iraku i Kurdów, w obliczu konfliktu z tzw. Państwem Islamskim w latach 2014-2017. Cz. 2 - Czechy. Instytut Nowej Europy. Pobrane z: http://ine.org.pl/dzialania-panstw-grupy-wyszehradzkiej-na-rzecz-iraku-i-kurdow-w-obliczu-konfliktu- z-tzw-panstwem-islamskim-w-latach-2014-2017-cz-1-slowacja/. 
Kratochvílová, L. (2018, 27 lutego). Pražský soud propustil zadrženého kurdského politika Sáliha Muslima. Globe24. Pobrane z: https://globe24.cz/domov/50695-prazsky-soud-propustil-zadrzeneho-kurdskeho-politika-saliha-muslima.

Malý, M. (2020, 29 stycznia). Džihád v České republice. Teroristický útok zmařen. A př́štěe? Bez Politicke Korektnosti. Pobrane z: http://www.bezpolitickekorektnosti. $\mathrm{cz} / \mathrm{p} \mathrm{p}=93139$.

Mareš, M., Petlák, J. (2019, 8 stycznia). Violent Extremism in the Czech Republic. European Eye on Radicalization. Pobrane $\mathrm{z}$ : https://eeradicalization.com/violent-extremism -in-the-czech-republic.

Mareschal, E., Piquet, C. (2018, 24 marca). Attaques dans l'Aude: une proche du suspect placée en garde à vue. Le Figaro. Pobrane z: https://www.lefigaro.fr/actualite-france/2018/03/23/01016-20180323LIVWWW00116-en-direct-aude-prise-dotage-pres-de-carcassonne-des-crs-pris-pour-cible.php.

Marszałek-Kawa, J., Plecka, D., Hołub, A. (red.). (2018). Social Security. Selected Aspects. Toruń: Wydawnictwo Adam Marszałek.

Masakr v ostravské nemocnici: Střelba má 7. obět’ zemřela těžce zraněná žena. $(2019,10$ grudnia). Blesk.cz. Pobrane z: blesk.cz/clanek/regiony-ostrava/628405/online-masakr-v-ostravske-nemocnici-strelba-ma-7-obet-zemrela-tezce-zranena-zena.html.

Mikelionis, L. (2018, 25 marca). Alleged ISIS terror cell busted in Europe, Iraqi man suspected of carrying out 2 unsuccessful German train attacks. Fox News. Pobrane z: www. foxnews.com/world/alleged-isis-terror-cell-busted-in-europe-iraqi-man-suspected-of-carrying-out-2-unsuccessful-german-train-attacks.

Ministerstvo dopravy. (2019, 4 lipca). Workshop Ministerstva dopravy $k$ problematice ochrany měkkých cílů $v$ dopravě. Pobrane z: www.mdcr.cz/Dokumenty/Ministerstvo/ Krizove-rizeni-MD/Workshop-rezortu-MD-k-problematice-ochrany-mekkych.

Ministerstvo vnitra České republiky. (2013). Strategie České republiky pro boj proti terorismu od r. 2013. Praha: Ministerstvo vnitra České republiky.

Ministerstvo vnitra České republiky. (2017). Zpráva o situaci v oblasti vnitřní bezpečnosti a veřejného pořádku na území České republiky v roce 2016. Praha: Ministerstvo vnitra ČR, odbor bezpečnostní politiky a prevence kriminality.

Ministerstvo vnitra České republiky. (2018). Zpráva o extremismu na území České republiky v roce 2017. Praha: Odbor bezpečnostní politiky Ministerstva vnitra.

Ministerstvo vnitra České republiky. (2019a). Zpráva o projevech extremismu a predsudečné nenávisti na území České republiky v roce 2018. Praha: Odbor bezpečnostní politiky Ministerstva vnitra.

Ministerstvo vnitra České republiky. (2019b). Zpráva o situaci v oblasti vnitřní bezpečnosti a veřejného pořádku na území České republiky v roce 2018. Praha: Ministerstvo vnitra ČR, odbor bezpečnostní politiky a prevence kriminality.

Ministerstvo vnitra České republiky. (2020, 3 lutego). Stupně ohrožení terorismem. Pobrane z: mvcr.cz/cthh/clanek/stupne-ohrozeni-terorismem.aspx.

Ministry of the Interior of the Czech Republic. (2016). National Security Audit. Prague: Ministry of the Interior of the Czech Republic, Security Policy and Crime Prevention Department.

Ministry of the Interior of the Czech Republic. (2018). Situation Report on Internal Security and Public Order in the Czech Republic in 2017. Prague: Ministry of the Interior of the Czech Republic. 
Nalepa, T., Popiel, S. (2009). Terroryzm chemiczny, Przegląd Bezpieczeństwa Wewnętrznego, 1, 61-76.

Nusra Front (Jabhat Fateh al-Sham). (b.d.). Counter Extremism Project. Pobrane z: https://www.counterextremism.com/threat/nusra-front-jabhat-fateh-al-sham.

Olech, A.K. (2019). Zagrożenie terrorystyczne w Republice Francuskiej - analiza źródet $i$ wywiady eksperckie cz. 2. Instytut Nowej Europy. Pobrane z: http://ine.org.pl/ zagrozenie-terrorystyczne-w-republice-francuskiej-analiza-zrodel-i-wywiady-eksperckie-cz-2/.

Phillips, J. (2004, 16 marca). Spain's Retreat After The Madrid Bombings Rewards Terrorism. The Heritage Foundation. Pobrane z: https://www.heritage.org/europe/report/ spains-retreat-after-the-madrid-bombings-rewards-terrorism.

Radek Rozvoral: Kontrarozvědka BIS - teroristický útok hrozí i v České republice! (2015, 2 września). Svoboda a Př́má demokracie. Pobrane z: www.spd.cz/novinky/ radek-rozvoral-kontrarozvedka-bis-teroristicky-utok-hrozi-i-v-ceske-republice.

Schüllerová, B., Mika, O.J., Adamec, V. (2014). Threat of chemical terrorism in the underground. Transactions of the VŠB - Technical university of Ostrava IX(2), 46-52.

Slonková, S. (2016, 25 sierpnia). Tajné služby řeši šifrovanou zprávu bývalého pražského imáma. Neovlivni. Pobrane z: http://neovlivni.cz/tajne-sluzby-resisifrovanou-zpravu-byvaleho-prazskeho-imama/.

Smale, A., de Goeij, H. (2014, 1 stycznia). Blast Kills Palestinian, a Diplomat, in Prague. New York Times. Pobrane z: nytimes.com/2014/01/02/world/europe/Palestinian-ambassador-dies-in-Prague.html.

Speckhard, A. (2009). The Militant Jihad in Europe: Fighting Home Grown Terrorism. NATO Science for Peace and Security Series - E: Human and Societal Dynamics, 60, 143-160.

Teroristé vyhledávají „měkké cíle”. Počet jejich útoků v Evropě od roku 2014 podstatně stoupl. (2016, 20 lipca). Aktualne.cz. Pobrane z: https://zpravy.aktualne.cz/zahranici/\%C4\%8CTKeuropol-upozornil-na-lonsky-narust-obeti-teroristickych-utok/ r 9c556a8c4e8111e69966002590604f2e/.

Tichý, L. (2016, 19 grudnia). Hrozí v Evropě útoky na energetický sektor ze strany Islámského státu? Zahraničná politika. Pobrane z: https://zahranicnapolitika.sk/ hrozi-v-evrope-utoky-na-energeticky-sektor-ze-strany-islamskeho-statu.

Trestní zákoník č. 40/2009 Sb.

United Nations Office On Drugs And Crime. (2018). Education for justice university module series counter-terrorism - Module 1 introduction to international terrorism. Vienna: United Nations.

Utok na Merkelovou: do kolony vjel agresivní řidič v džípu! (2016, 25 sierpnia). TV Nova. Pobrane z: https://tn.nova.cz/clanek/naruseni-bezpecnosti-ridic-vjizdel-do-kolony-merkelove.html.

Zabłocki, E. (2013). Kategorie, zagrożenia: system bezpieczeństwa narodowego. Warszawa: Wyższa Szkoła Informatyki, Zarządzania i Administracji.

Zeman: Refugees should be promptly returned, not accommodated. (2015, 31 sierpnia). Prague Daily Monitor. Pobrane z: http://www.praguemonitor.com/2015/08/31/ zeman-refugees-should-be-promptly-returned-not-accommodated. 